\title{
設計概念生成のための新規性ポテンシャルの考え方と 単語類似度計測によるその評価法の提案
}

\author{
野間口 ${ }^{*}{ }^{*}$, 河原 貴大 ${ }^{*}$, 正田 浩暉 ${ }^{*} 2$, 藤田 喜久雄 ${ }^{*} 1$
}

\section{Proposal of the novelty potential for design concept generation and its assessment method with word similarity}

\author{
Yutaka NOMAGUCHI ${ }^{* 1}$, Takahiro KAWAHARA ${ }^{* 2}$, Koki SHODA ${ }^{* 2}$ and Kikuo FUJITA ${ }^{* 1}$ \\ ${ }^{*} 1,{ }^{*} 2$ Department of Mechanical Engineering, Graduate School of Engineering, Osaka University \\ 2-1 Yamadaoka, Suita-shi, Osaka 565-0871, Japan
}

Received: 31 December 2019; Revised: 26 August 2020; Accepted: 25 September 2020

\begin{abstract}
Generating novel design concepts is a cornerstone for producing innovative products. Although many methods have been proposed for supporting the task, their performance depends on human ability. The ultimate goal of this research is to build a method supporting designers to generate novel design concepts with the knowledge of human creativity. Toward the goal, this research assumes that the more distant two function concepts chosen, the more novel idea would be come up with by the combination of the two concepts. Based on the assumption, this paper introduces a notion of novelty potential of the combination of two function concepts, and builds a method to assess it by the function similarity. Some alternative methods are proposed to calculate it with the integration of a lexical database for natural language called WordNet and a distributional semantics method called word2vec. They are verified with an evaluation experiment which performs correlation analysis between the human's evaluation of the novelty potential and the proposed method's assessment of function similarity. This paper discusses which method matches a human sense most, and its possibility for design concept generation based on the results of the experiment.
\end{abstract}

Keywords : Design engineering, Product Planning, Product Design, Idea generation and creativity support, Word similarity

1. 序論

製品設計開発では，既存製品の簡単な改善や既存技術の応用といったものからまったく新しい製品の開発まで， 程度の差はあれ，何らかの新しい概念の生成が求められる問題に取り組む必要がある (De Brentani, 2001) . 市場で の競争力を持つ革新的な製品を生み出すためには, 設計の上流段階において新しい設計概念を数多く生成し，そ れらの比較検討を通じて洗練化していくことが重要である. ブレインストーミング (Daly et al., 2016) は設計概念 生成のための手法としてよく知られているものの一つであるが, 体系的ではなくその成果は設計者の能力に強く 依存している.

設計工学分野においては，従来，設計概念生成を体系的に支援することを目指して，概念生成における設計者 の思考プロセスを理解するための理論 (Hatchuel and Weil, 2009)や, 設計者の創造性を客観的に評価するための指 標 (Ranjan et al., 2018)の開発が行われてきた. その中でも，一般設計学 (General Design Theory; GDT) (Yoshikawa,

\footnotetext{
No.20-00006 [DOI:10.1299/transjsme.20-00006], J-STAGE Advance Publication date : 6 October, 2020

${ }^{* 1}$ 正員, フェロー, 大阪大学大学院工学研究科機械工学専攻（广565-0871 大阪府吹田市山田丘 2-1)

*2 大阪大学大学院工学研究科機械工学専攻

E-mail of corresponding author: noma@mech.eng.osaka-u.ac.jp
} 
1981) は設計プロセスについての先駆的な理論である. GDT は集合理論に基づいて設計プロセスを概念とその集 合に対する操作としてモデル化し, 設計プロセスについての定理を数学的に導出している. その知見の一つは, 設 計者が新しい概念を生み出すきっかけとなるのは類概念の新しい組み合わせである, ということである.これら 設計理論についての先行研究は設計概念の生成支援を考える上で重要な基盤となる一方で, 体系的な支援手法の 確立には至っていない.

本研究の最終的な目標は, 設計概念生成についての理論的な知見に基づいて, 設計者が新しい設計概念を生成 する作業を体系的に支援するための手法を構築することである. それに向け, 本報では, 設計の上流段階におけ る主要な類概念として機能概念に着目し, 組み合わせる 2 つ機能概念の距離が大きいほど新規性の高い概念が 生成される (Chan et al., 2011, Taura and Nagai, 2013), との前提に立ち, 機能概念間の距離の客観的な評価法を開 発することを目的とする. 本報ではまず, 生成される概念の新規性の高さに対応する指標として「新規性ポテン シャル」を導入する. その上で, 自然言語処理の分野で開発されている単語類似度計測法の主要なアプローチで ある辞書アプローチ (lexical approach) と分布アプローチ (distributional approach) に着目し, それぞれの代表例と して WordNet (Miller, 1995)による手法と word2vec (Mikolov et al., 2013) を取り上げ, 両者の特徴を検討して, 機 能概念の距離計測に適した手法を提案する，評価実験では，まず，具体的な題材を取り上げて機能概念を収集す る. それらの組み合わせに対して, 人間の評価者による新規性ポテンシャルの評価值と, 提案手法による機能類 似度の計測值との相関分析を行い, 提案手法による評価が人間の評価に近いかどうかを検証する. 最後に, 提案 手法による設計概念生成支援の展望を考察する.

\section{2. 設計概念生成支援の従来研究と本研究のアプローチ}

\section{$2 \cdot 1$ 設計概念生成の理論}

設計概念生成についての従来研究を大別すると, 経験的アプローチと理論的アプローチに分類することができ る. 経験的アプローチは, 設計概念生成プロセスの事例を収集して, それらから設計者の思考のパターンを抽出 し，それに基づいて概念生成支援を行うものである. TRIZ (Altshuller, 2005) は250万件にも及ぶ特許の分析に基 づいてその中に見られる思考パターンを 40 の発明原理としてまとめ, それによる概念生成支援を行う手法であり, このアプローチの代表例といえる. また, Han ら (Han et al., 2018)は, 過去の事例から抽出された類推的思考のパ ターンのデータベースを備え, 設計者の設計解空間の拡張や解探査に役立つ Retriever という支援ツールを開発し ている.

理論的アプローチにおいては, 設計者の思考プロセスにおいて概念生成に関連する要因を洗い出し, 概念生成 の規範モデルを構築するとともに, 実際の設計結果の創造性を評価する指標を定義する研究が行われている (Fu et al., 2018). なかでも, 新規性は設計概念生成を考える上で必要不可欠な指標であり, 多くの研究者によってその評 価方法が提案されている．例えば，Shah らは，新規性に加え, 多様性, 優良性, および生成した概念の総数の 3 つを定義している (Shah et al., 2003). 総数以外の指標については, 設計者が構築した機能分解図から計測する手 法を提案している. Ranjan らは, 新規性と有用性の 2 つを創造性の指標として定義し, 生成した概念が設計要求 を満足する程度に基づいてそれらを計測する手法を提案している (Ranjan et al., 2018). これらの指標は, 設計者 の創造的な思考を説明するのに役立つと考えられる.

経験的アプローチは，体系的な概念生成支援のための手法を提供することができるが, 理論的な裏付けは必ず しも十分でないため, その効果の客観性, 普遍性に難点があり, 設計者の能力に頼るところが大きい. 一方で, 理 論的なアプローチは, どちらかといえば科学的な観点から概念生成プロセスの解明を目指すものであり, 支援手 法への展開には課題が残っている. 両者のアプローチの融合がこの方面の研究の重要な課題といえる.

\section{$2 \cdot 2$ 概念操作に基づく生成支援手法}

GDT は, 人間が持つ設計能力を科学的に明らかにし，それに基づいて設計支援に向けた実践的な知識を得るこ とを目的とした設計理論である (Yoshikawa, 1981). 設計概念空間の構造についての議論を, 集合論を用いて数学 的に進める点に特徵がある. 本研究では, GDT を, 設計概念生成プロセスの科学的説明のための基礎理論として 用いることとする. 


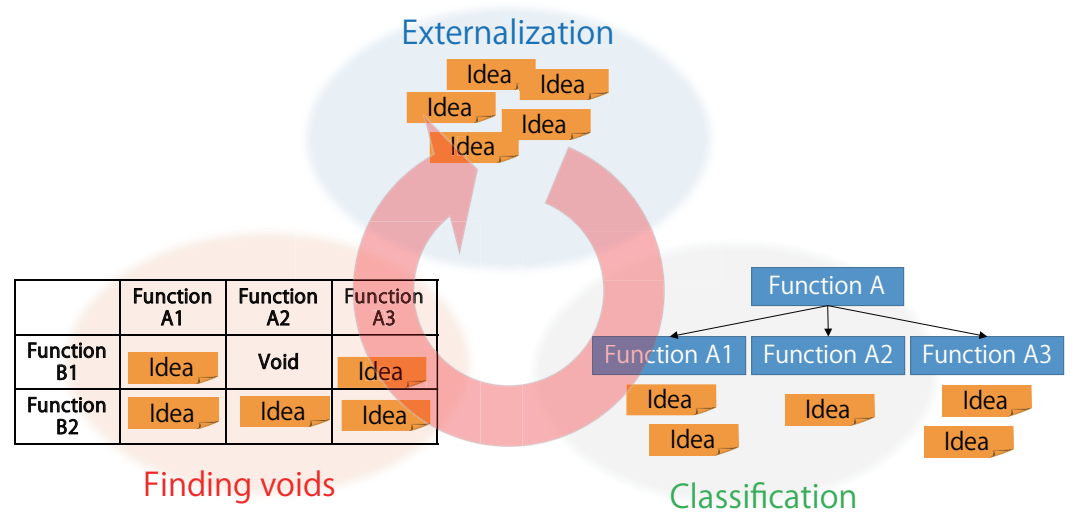

Fig. 1 ECF cycle consists of three steps, i.e., (1) Externalization: the step for representing design concepts with drawings and language, (2) Classification: the step for classifying concepts with function trees, and (3) Finding voids: the step for finding potentials of new concepts called void, which is a defect of the classification.

一般設計学において, 概念は, 設計解のアイデアに対応する実体概念と, 機能や物理的属性など実体の特徵を表 し, 実体概念の類概念となる抽象概念の 2 つに大別される. 設計者はアイデアを特徴づける抽象概念を組み合わ せながら新たな抽象概念を生成して, 設計概念の分類体系を構築していきつつ, 同時に, それぞれの抽象概念に 対応する実体概念を対応付けていく，そうすると既知の実体概念が対応しない空白の抽象概念がみつかる．これ が Void (Tomiyama et al., 2010) であり，設計者が思いついていない未知の概念が示唆される．すなわち，Voidの 発見が，新たな概念の生成の契機となるのである. Voidの考え方は，人間が新しい概念を生成するプロセスにお いて分類体系や概念操作が重要な役割と果たすことを端的に示している.

著者らのグループでは，Voidの考え方に基づいて，ECF サイクルと呼ぶ概念生成プロセスのモデルを提案して いる (野間口他, 2017)．ECF サイクルによれば, 図 1 に示すように, 既存の設計概念の外在化 (Externalization), 設計概念の分類 (Classification), Void 発見 (Finding void)の3つの段階の連鎖により概念の生成が行われる. 著者 らの先行研究 (野間口他, 2017) においては, 分類段階で機能オントロジーを, 外在化段階で TRIZ 発明原理を活用 することによる生成支援手法を提案し，その有効性を設計例題を通じて検証している。一方で Void 発見段階につ

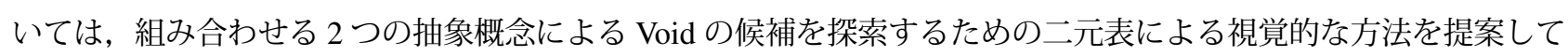
いるものの, 組み合わせる抽象概念の選択は設計者の判断に依存している.

\section{$2 \cdot 3$ 本研究のアプローチ}

$2 \cdot 1$ 節で述べたように，設計概念の生成支援についての従来研究には，実践面と理論面の両立に課題がある. $2 \cdot 2$ 節で述べた GDT およびそれを基にした ECF サイクルは設計概念生成のための理論となり得るが，Void 発見段階 において組み合わせるべき抽象概念の選択方法が確立されていないなど，体系的な手法への展開に課題が残され ている.

設計概念生成支援に関する理論的アプローチのうち類推推論に着目した先行研究 (Chan et al., 2011, Taura and Nagai, 2013)によれば, 課題解決を他分野の知識からの類推により行う場合, より距離の遠い分野の知識を使うこ とによりより新規性の高い解が得られることが報告されている. 本研究では, この知見を踏まえ，より遠い距離 の抽象概念を組み合わせることにより, より新規性の高い設計概念を生み出すことができる, との前提に立って, ECF サイクルの Void 発見段階において新規性の高い設計概念を生み出す可能性の高い抽象概念の組み合わせを選 択する上での指針を確立することを考える.

本研究では, 抽象概念として, 設計の上流段階で特に重要となる機能概念に着目する. 近年のデータサイエンス に基づく人工知能技術の進展により, 大量の自然言語データを効率的かつ客観的に処理することが可能となって いる. 本研究ではその技術を活用して機能概念間の類似度を計測し，新規性ポテンシャルを客観的に評価する手 法を確立する. 


\section{3. 新規性ポテンシャルと機能概念類似度によるその計測手法}

本章ではまず, 設計において距離が果たす役割を考察し, それを踏まえて, 新規性ポテンシャルの考え方を導入 する. 次に, 設計概念生成支援の観点から機能概念の表現法について検討した上で, 既存の単語間類似度の測定 法を概観し, 機能概念類似度の計測の観点から比較検討を行う. 最後に, 機能概念類似度の測定法を提案する.

\section{$3 \cdot 1$ 設計における距離の役割から考える新規性ポテンシャル}

設計においては，一般に，設計解候補が機能などの要求を満足している程度を判定し，それに基づいてより良 い解に向けて修正・変更していく, ある種の探索が行われる. 数理計画法を基盤とした最適化計算は, 概念設計を 経て解候補の内容がある程度具体化された段階において, 探索を実施するための合理的かつ有力な手段である (山 川, 2003) . 最適設計が合理的な手法として成立するためには, 設計問題と解候補が数理的に表現でき, 要求の内 容と解候補の持つ属性の内容との距離を明確に定義できることが前提となっている.

一方で，概念設計を含む設計の上流段階においては，設計問題も解候補も概念的であり，数理表現が可能である ほど具体化されていないことが多く, 距離の定義は自明ではない.しかし, 2.3 節で述べた先行研究 (Chan et al., 2011, Taura and Nagai, 2013)の知見に従えば, 設計の上流段階においても設計者は概念間の距離を何らかの基準で 測定し，より良い解候補，すなわち，より新規性の高い設計概念を探索していると考えられる.

本研究で導入する新規性ポテンシャルは，そもそも測定が困難な概念間の距離を，2.2 節で述べた Void の考え 方に基づいた概念生成を効果的に進められるように，すなわち，2つの機能概念の組み合わせにより新しい設計概 念が生み出される可能性の大きさを定量化するように, 導入するものである. 具体的には, 新規性ポテンシャル を「2つの機能概念の両方を持つ実体概念 (自然物と人工物の両方を含む) を設計者が思いつく難しさの度合」と 定義する.

本研究では, 以下のように基準を設けて 3 段階で評価することとする.

・ 1: ありふれた概念の組み合わせであり，2つの機能を持つ実体概念をすぐに思いつくことができる.

・2: 一般的でない概念の組み合わせであるが，しばらく考えれば，2つの機能を持つ発現する実体概念を思い つくことができる.

・ 3: 一般的でない概念の組み合せであり, 十分な時間をかけても 2 つ機能を持つ実体概念を思いつくことが できない.

\section{$3 \cdot 2$ 対象とする機能表現}

機能表現の方法には, 大きく分けて, 「動詞・目的語」の形式で表現する方法と,「入力・出力」の形式で表現す る方法の 2 つがある (冨山, 2002) . 前者はより柔軟な表現能力を持ち, 設計の上流段階での機能概念の表現が比 較的容易であるため, 本研究で着目する設計概念生成での利用に適している.

本研究では, より柔軟な表現に対応するため, 前者のアプローチを拡張した表現法である, 動詞・目的語・修 飾語の形式の機能表現法 (Shimomura et al., 1998)を採用する.

\section{$3 \cdot 3$ 単語間類似度の計測法}

自然言語処理は人工知能分野において古くから取り組まれており, なかでも, 単語間類似度計測は文書検索結果 の順位付けなどに用いられる重要な技術である. 設計工学の分野においても, 自然言語表現のもとでの機能をはじ めとする設計概念の類似度の計測 (Cheong et al., 2017)や, 概念生成プロセスの特徵の分析 (Georgiev and Georgiev,

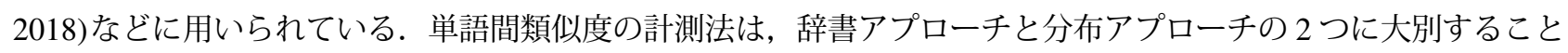
ができる.

\subsection{1 辞書アプローチによる単語間類似度}

辞書アプローチは, 単語間に存在する類義語, 対義語などの意味を踏まえた階層関係を定義した辞書を用いて 距離を計測する方法である. WordNet (Miller, 1995) はその用途の辞書としてよく利用される. WordNet はもとも とは英語で開発され，その後，様々な言語に展開されている. 


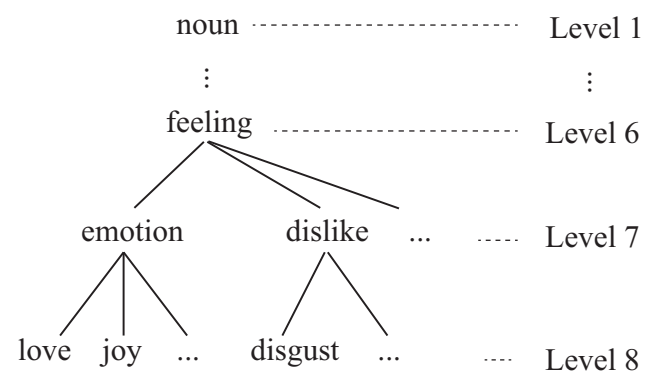

Fig. 2 Example of word hierarchy. The word similality is measured with the depth of words.

辞書アプローチによる単語間類似度は，一般に，計測対象の 2 つの語の階層の深さの差に基づいて定義され る (Rada et al., 1989). 以下の式は, 2 つの単語 $w_{1}$ および $w_{2}$ の距離 $s_{l}\left(w_{1}, w_{2}\right)$ の一例である.

$$
s_{l}\left(w_{1}, w_{2}\right)=\frac{2 d_{c}}{d_{1}+d_{2}}
$$

ここで， $d_{1}$ および $d_{2}$ は，それぞれ，辞書データベースにおける $w_{1}$ および $w_{2}$ の階層の染さを表す． $d_{c}$ は $w_{1}$ と $w_{2}$ の共通の上位語 $w_{c}$ の階層の深さである. 図 2 は名詞の階層の例である. ここで, “love” と “joy” の類似度を式 (1) により計測すると, いずれも階層の深さが 8 , 共通上位語“emotion” の階層の涾さが 7 であるから, $\frac{2 \times 7}{8+8}=0.875$ と なる，一方で，“love”と“disgust”の類似度を考える場合，いずれも階層の深さは 8 であるが，共通上位語 “feeling” の階層の深さが 6 であるから, $\frac{2 \times 6}{8+8}=0.75$ となる. つまり, “love”と“joy”よりも類似度が低いことが分かる.

なお, 単語の上位語が複数存在し，その階層の深さが一意に決まらない場合がある. 本研究では, 計測対象と なっている単語を含む機能表現の意味を踏まえて, もっとも適切な上位語を人間が選択することで深さを一意に 決めることとする.

\subsection{2 分布アプローチによる単語間類似度}

分布アプローチは, SNS やWeb ページなど実社会で作成された大量のテキストデータから, 何らかの統計処理 を用いて単語間の関係を自動的に抽出し，それに基づいて距離を計測するする方法である. 同じ文脈で利用され る複数の単語は同じ意味を持つ傾向がある，とする仮説に基づいており，一般にこれを分布仮説と呼ぶ.

word2vec (Mikolov et al., 2013) は，近年，よく利用される分布アプローチの手法である． word2vecでは，大量 のテキストを学習データとして用い，2層のニューラルネットワークを利用して単語の言語学的文脈をモデル化す る. 学習の結果, 数百次元のベクトル空間が生成され，1つの単語がその空間内の 1 つのベクトルに対応する. 学 習に用いたテキストデータにおいて近接して用いられる頻度が高い単語群は, ベクトル空間内でも近傍のベクト ルとなる. ベクトル空間では，2つのベクトル間にコサイン類似度を定義することができ，これが分布アプローチ における単語間距離として用いられる. 具体的には, 2 つの単語 $w_{1}$ および $w_{2}$ の距離 $s_{d}\left(w_{1}, w_{2}\right)$ は以下の式で与 えられる.

$$
s_{d}\left(w_{1}, w_{2}\right)=\cos \left(\boldsymbol{w}_{1}, \boldsymbol{w}_{2}\right)=\frac{\boldsymbol{w}_{1} \cdot \boldsymbol{w}_{2}}{\left|\boldsymbol{w}_{1}\right|\left|\boldsymbol{w}_{2}\right|}
$$

ここで, $\boldsymbol{w}_{1}$ および $\boldsymbol{w}_{2}$ は， $w_{1}$ および $w_{2}$ に対応するべクトルである. $\quad \cos \left(\boldsymbol{w}_{1}, \boldsymbol{w}_{2}\right)$ は $\boldsymbol{w}_{1}$ と $\boldsymbol{w}_{2}$ のコサイン類似 度である.

\subsubsection{2 つのアプローチの利点と欠点}

辞書アプローチと分布アプローチの利点と欠点について, 対義語・類義語の取り扱い, 句の取り扱い, 自動化 のしやすさ, 語義的な正しさ, の 4 つの評価項目から考察する. 表 1 は 4 つの観点での比較検討の内容をまとめ たものであり, ‘+'は優れていることを示している. 
Table 1 Comparison of word similarity approaches.

\begin{tabular}{lcc} 
Criteria & Lexical approach & Distributional approach \\
\hline \hline 1. Synonymous and antonym & + & - \\
\hline 2. Phrase similarity & - & + \\
\hline 3. Automation & - & + \\
\hline 4. Semantic correctness & + & - \\
\hline \hline Popular method & WordNet & word2vec \\
\hline
\end{tabular}

第 1 の評価項目について, 辞書アプローチは, 類義語, 対義語について注意深く構築された辞書に基づいて, 単 語間の関係を調べることができる，一方で，分布アプローチにおいては，分布仮説に基づく性質上，類義語，対義 語の区別は明確ではない，こうした性質を踏まえ，一般に，辞書アプローチはより抽象度の高い単語間の類似度の 計測に適しており，分布アプローチは具体的な単語間の類似度の計測に適していることが指摘されている (Cheong et al., 2017).

第 2 の評価項目は，機能概念を取り扱う上では最も重要なものである．機能概念は一般に，単一の語ではなく 複数の単語の組により表現される. 機能概念の類似度を計測するためには, そのような形式の考慮が必要である. この点に関しては分布アプローチが優れている．分布アプローチでは，句に対応するベクトルを，句を構成する 単語に対応するべクトルの線形和として容易に定義することができる. 辞書アプローチではそのような操作は不 可能である.

第 3，第 4 の評価項目は互いにトレードオフの関係にある，一般に単語は多義的で，同じ単語が異なる文脈では 異なる意味を持つことも多い. 辞書を使って単語の意味をたどることは可能であるが，その作業は完全に自動化 されず，人間の介在が不可欠である. 分布アプローチにおいては，テキストデータに基づく学習が完了した後は， 人間の作業を介さなくても，学習データに即した類似度計測結果を得ることができるが，多義的な単語の解釈に 一定程度の誤りが含まれる可能性を排除できない.

\section{4 機能概念類似度の計測法の検討}

3.3 節の議論を踏まえれば，2つのアプローチにはそれぞれ利点と欠点があり, 機能概念類似度の計測に適用す るにあたり，両者を補完する手法を検討する必要があると考えられる．例えば，Suryadi らは，Web ページに記載 された製品のユーザーレビューに基づいて類似の特徵を持つ製品群を特定する手法を提案している (Suryadi and Kim, 2017) 。この手法では, word2vecを単語類似度の計測に, WordNetを製品群間の類似度の計測に用いている. Cheong らは, 入力・出力形式で記述された機能表現の類似度を, word2vec による類似度と WordNet による類似 度の線形和により計算する手法を提案している (Cheong et al., 2017).

本研究では, 3.2 節で述べた動詞・目的語・修飾語の形式の機能表現に適した類似度計測法を提案する. 機能概 念の類似度計測において表 1 の第 2 項目が最も重要であることを踏まえれば，その点で有利な分布アプローチを 主に活用し，辞書アプローチを補完的に用いることを考える．具体的には，機能表現においては主要な役割を果 たす動詞に対して辞書アプローチによる類似度測定を行うことを考える．3.3.3 項で述べたように, 辞書情報の活 用にかかる負担と語義的正確さにはトレードオフの関係がある. 本研究ではケーススタディーを通じて辞書アプ ローチによる補完の効果を分析する.

以上の考察を踏まえて，下記の計測法を提案する．ここで， $f_{1}$ および $f_{2}$ は類似度測定の対象となる 2 つ機能 概念を, $v_{i}, o_{i}, m_{i}$ は機能概念 $i$ における動詞, 目的語, 修飾語を, それぞれ表す.

1. $f_{i}$ に対応するべクトルを, 動詞に対応するベクトル $\boldsymbol{v}_{i}$, 目的語に対応するベクトル $\boldsymbol{o}_{i}$, 修飾語に対応するべ クトル $\boldsymbol{m}_{i}$ の線形和による以下の式で定義する.

$$
\boldsymbol{f}_{i}=\frac{1}{N}\left(\boldsymbol{v}_{i}+\boldsymbol{o}_{i}+\boldsymbol{m}_{i}\right)
$$

・動詞，目的語，修飾語のそれぞれが果たす役割の大きさの違いを踏まえて線形加重和を用いることも考 えられるが, 加重の調整が課題となる. 本研究では, 計測手法を簡略化するため, 均等加重の線形和を 考える.

・本研究では，機能表現において $o_{i}$ および $m_{i}$ が久落する場合も許容する．その場合には，久落した語に対 
応するべクトルを 0 とする. $N$ は, $\boldsymbol{v}_{i}, \boldsymbol{o}_{i}, \boldsymbol{m}_{i}$ のうちの非ゼロベクトルであるものの数であり, $1 \leq N \leq 3$ である.

•もし, $v_{i}, o_{i}, m_{i}$ のいずれかが複数の単語から構成される句である場合, そのベクトルをそれぞれの単語 のベクトルの線形和で与える. 例えば, 修飾語 $m_{i}$ が $M$ 個の単語 $w_{1}, w_{2}, \cdots, w_{M}$ から構成される場合, そ のベクトルを以下の式で与える.

$$
\boldsymbol{m}_{i}=\frac{1}{M} \sum_{j=1}^{M} \boldsymbol{w}_{j}
$$

2. $f_{1}$ と $f_{2}$ の分布アプローチによる類似度を分布類似度 (distributional similarity) と呼ぶ. 式 (2) に基づき, $f_{1}$ と $f_{2}$ のコサイン類似度を与える以下の式で定義する.

$$
s_{d}\left(f_{1}, f_{2}\right)=\cos \left(\boldsymbol{f}_{1}, \boldsymbol{f}_{2}\right)
$$

3. $f_{1}$ と $f_{2}$ の辞書アプローチによる類似度を辞書類似度 (lexical similarity) と呼ぶ. 式(1)に基づき, 動詞間の類 似度を与える以下の式で定義する。

$$
s_{l}\left(f_{1}, f_{2}\right)=s_{l}\left(v_{1}, v_{2}\right)
$$

4. $f_{1}$ と $f_{2}$ の類似度を辞書アプローチおよび分布アプローチを組み合わせて与えたものを補完類似度 (complemented similarity) と呼び, 分布類似度と辞書類似度の平均による以下の式で与える.

$$
s_{c}\left(f_{1}, f_{2}\right)=\frac{1}{2}\left(s_{d}+s_{l}\right)
$$

なお, 設計者はしばしば機能表現における動詞句を否定形や受動態で表現することがある. 本研究では, 設計者 の自由な思考プロセスを妨げないようにするため，そのような表現も受け入れることとする．それらは文法上の 意味は異なるが, 機能表現としては同類の概念とみなすことができる. 例えば, 「〜を動かすこと」,「〜を動かさ ないこと」,「〜に動かされること」はいずれも移動についての機能表現とみなすことができる. 本研究では, そ れらは動詞はすべて原形の表現と同等に扱い，本節で定義した各式を用いることとする.

\section{4. 評 価 実 験}

\section{$4 \cdot 1$ 実験の方法}

本研究では, 3.4 節で提案した各手法による機能類似度の評価を, 人間による新規性ポテンシャルの評価に対し て比較し, それが人間の評価と相関を持つことを検証する. そのための評価実験を, 図 3 の 1 4 の手順で行う. それぞれの詳細を下記に示す。

1. 機能概念の組の収集：まず, 評価実験の材料となる機能概念の組み合わせを収集する. 2.3 節で述べたように, 本研究で提示する計測手法は, ECF サイクルの Void 発見段階において新規性ポテンシャルの高い Void を選 択するために活用することを想定している. そのため, 評価実験におけるデータにも, 新規性ポテンシャル の高いVoid を形成するような機能概念の組を用いるのが望ましいと考えられる. そこで, すでに市場に出て いるがまだそれほど一般的でない新規性の高い製品を取り上げて, 複数の被験者に提示し，その製品の概念

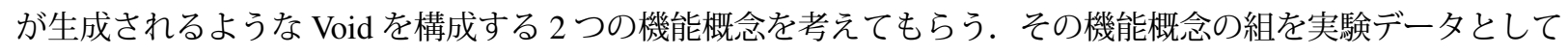
収集する。

2. 人間の評価者による新規性ポテンシャルの評価：1で収集した機能概念の組に対し, 複数の人間の評価者が, その新規性ポテンシャルを評価する. この評価は，3.1 節で提示した 3 段階で行う. なお, 評価者が機能表現 のみを見て評価を行うことができるようにするため, 評価者には，1で被験者に提示した製品の内容を伝えな いものとする. 


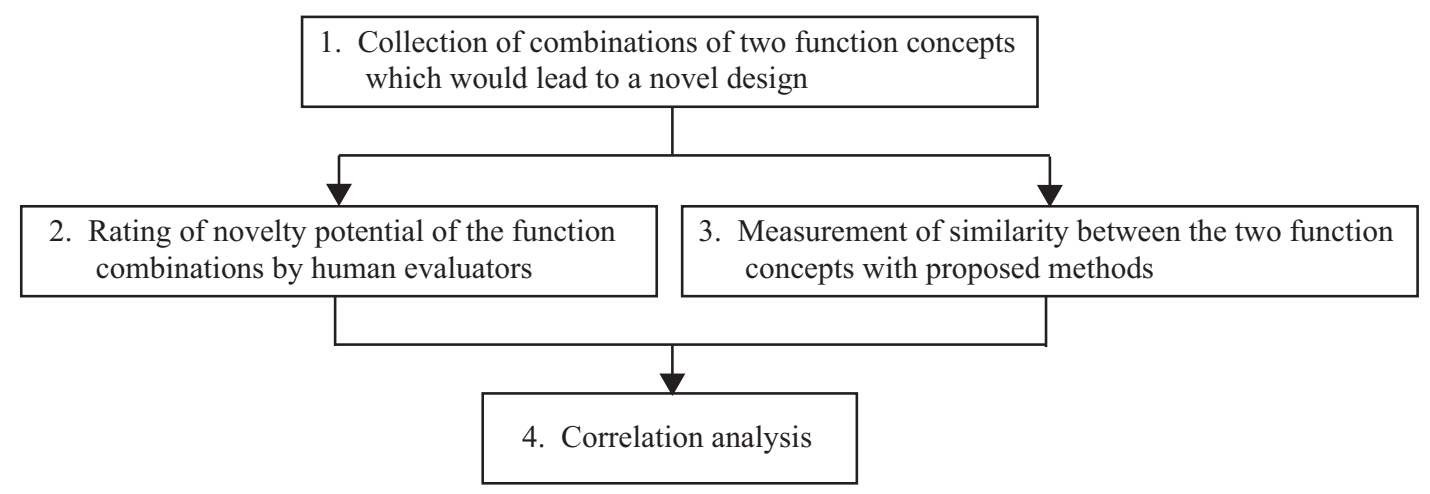

Fig. 3 Overview of evalation experiment.

\section{3. 提案手法による機能類似度の計測 :}

1 で収集した機能概念の組に対し， 3.4 節で提案した各手法による機能類似度の評価を行う. 本研究では, 辞書 類似度の計測には英語版 WordNetを，分布類似度の計測には英語版 Wikipedia を学習データとした word2vec を用いる. Wikipedia は誰もが編集可能な百科事典であり, その内容の信頼性は必ずしも高いとは言えないが, 他の SNS などと比べれば信頼できる情報源であり，また，ニューラルネットワークによる学習を行うのに十 分な量のテキストデータを得ることができることから，本研究で採用することとする.

word2vec の単語ベクトル作成にあたっては，フリーライブラリ Phython gensim ${ }^{1}$ の CBOW (Continuous BagOf-Words) モデルを利用する. このモデルは学習コストが比較的小さく, 様々な用途に使われていることから, 本研究でも採用することとする. 単語べクトルの次元数, および文脈として認識する単語数は, 一般に使わ れる值を採用して，それぞれ 200, 15 とする.

計測の際，1で収集した日本語の機能表現を，実験者である著者らが，英語版 WordNet に掲載され，かつ， word2vecにより学習された英単語を用いて英語に翻訳する. 翻訳の際には, 適宜, 複数の実験者が討議を行 い翻訳の妥当性を検証する.

4. 相関分析：最後に, 2 の評価值と, 3 の計測值の相関を分析する.

なお, 本研究の被験者は, 大阪大学大学院工学研究科機械工学専攻設計工学領域に所属する大学院生 8 名であ る. 評価者は, 同所属の, 被験者とは異なる大学院生 3 名である.

\section{$4 \cdot 2$ 題材として取り上げる製品}

前節の 1 において提示する製品として, 本研究では, ポットインポットクーラー (Smith, 2007) とアドスペック ス (Douali and Silver, 2004)の 2 つの製品を取り上げる.

ポットインポットクーラーは, 気化熱を利用することで電気を使わずに食料を冷蔵保存することができる冷蔵

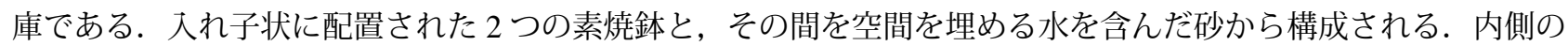
鉢の中に保存したい食料を入れておくと，砂に浸透した水が蒸発する際に気化熱を奪い，鉢の内側の温度を下げ て，食料を冷蔵することができる.アドスペックスは発展途上国のユーザー向けに開発された低コストの眼鏡で ある.この眼鏡はシリコンオイルが充填された樹脂を装着しており, ユーザーは自分でシリコンオイルの量を自 由に調節し，レンズの焦点距離を変更できる. 通常は専門の医が行う度数の調整を, レンズを交換することなし にユーザー自らが行うことができる.

いずれの製品も発展途上国では実際に実用化されているが，本実験の被験者，評価者にはなじみがない．この ことから本研究の評価実験の題材として取り上げる新規性の高い製品として適していると考えられる. また, 複

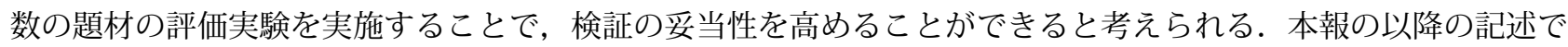
は，ポットインポットクーラーを題材とする実験を (A)，アドスペックスを題材とする実験を (B) と表記する.

\footnotetext{
${ }^{1}$ https://radimrehurek.com/gensim/index.html
} 
Table 2 Collected function concepts, measured similarities and rated novelty potential in design experiment (A): Pot-in-pot refrigerator.

\begin{tabular}{lllllll} 
No. & $f_{1}$ & $f_{2}$ & $s_{l}\left(f_{1}, f_{2}\right)$ & $s_{d}\left(f_{1}, f_{2}\right)$ & $s_{c}\left(f_{1}, f_{2}\right)$ & $N P$ \\
\hline \hline 1 & to refrigerate food & to use natural phenomenon & 0.333 & 0.250 & 0.292 & 2.3 \\
\hline 2 & to refrigerate food & to use energy & 0.333 & 0.345 & 0.339 & 1.7 \\
\hline 3 & to repeat action & to use heat vaporization & 0.333 & 0.209 & 0.271 & 3.0 \\
\hline 4 & to change surroundings & to use electric power & 0.500 & 0.340 & 0.420 & 1.0 \\
\hline 5 & to use natural phenomenon & to refrigerate food & 0.333 & 0.250 & 0.292 & 1.7 \\
\hline 6 & to keep low temperature & to use small space & 0.400 & 0.400 & 0.400 & 1.7 \\
\hline 7 & $\begin{array}{l}\text { to use heat vaporization or heat } \\
\text { fusion }\end{array}$ & to confine cold air & 0.333 & 0.401 & 0.367 & 2.0 \\
\hline
\end{tabular}

One examinee is absent in this experiment.

Table 3 Collected function concepts, measured similarities and rated novelty potential in design experiment (B): Adspecs.

\begin{tabular}{|c|c|c|c|c|c|c|}
\hline No. & $f_{1}$ & $f_{2}$ & $s_{l}\left(f_{1}, f_{2}\right)$ & $s_{d}\left(f_{1}, f_{2}\right)$ & $s_{c}\left(f_{1}, f_{2}\right)$ & $N P$ \\
\hline 1 & $\begin{array}{l}\text { to complement bodily function } \\
\text { with different shape }\end{array}$ & to adjust focal distance always & 0.667 & 0.496 & 0.581 & 1.3 \\
\hline 2 & to adjust focal distance always & to wear & 0.333 & 0.146 & 0.240 & 1.7 \\
\hline 3 & $\begin{array}{l}\text { to change lens thickness by } \\
\text { transformation }\end{array}$ & to wear & 0.400 & 0.232 & 0.316 & 3.0 \\
\hline 4 & $\begin{array}{l}\text { to change sight with liquid } \\
\text { refractive index }\end{array}$ & to wear & 0.400 & 0.259 & 0.330 & 3.0 \\
\hline 5 & $\begin{array}{l}\text { to adjust focal distance by } \\
\text { changing thickness of lens }\end{array}$ & to fit people universally & 0.571 & 0.226 & 0.399 & 2.3 \\
\hline 6 & to wear & $\begin{array}{l}\text { to customize focal distance } \\
\text { without changing component }\end{array}$ & 0.571 & 0.226 & 0.399 & 2.3 \\
\hline 7 & to wear & $\begin{array}{l}\text { to adjust focal distance without } \\
\text { doctor }\end{array}$ & 0.333 & 0.076 & 0.205 & 3.0 \\
\hline 8 & to reinforce bodily function & to adjust focal distance easily & 0.571 & 0.421 & 0.496 & 1.0 \\
\hline
\end{tabular}

\section{$4 \cdot 3$ 実験結果}

表 2 および表 3 は，それぞれ，実験 (A) および実験 (B) を通じて収集されたデータをまとめたものである. 各 表には, 被験者番号, 被験者が設定した 2 つの機能概念 $f_{1}, f_{2}$ を英訳し, 3.4 節の方針に従って肯定形, 能動態 の形式に揃えた表現, 式 (6) により計算した辞書類似度 $s_{l}\left(f_{1}, f_{2}\right)$, 式 (5) により計算した分布類似度 $s_{d}\left(f_{1}, f_{2}\right)$, 式 (7)により計算した補完類似度 $s_{c}\left(f_{1}, f_{2}\right)$, および, 評価者による新規性ポテンシャルの評価值 $N P$ が示されている. なお，NPの值は，各評価者による 3.1 節の 3 段階のスケールのもとでの評価值を集計し，平均值をとったもので ある.実験 (A) では 1 名の被験者が参加していないため，7名の被験者のデータを用いている.

表 2 および表 3 の結果によると，2つの設計実験における機能表現には明確な違いがみられる. 実験 (A) ではい ずれの被験者も修飾語を一切用いていない.一方で, 実験 (B) では, いずれの被験者も，2つの機能概念の片方ま たは両方で修飾語を用いている。こうした差異は意図せずに得られたものであるが，提案手法の計測能力を議論 する際に役立つと考えられる.

図 4 に，実験 (A) および (B) における機能類似度の計測值と，新規性ポテンシャルの評価值との相関分析の結果 を示す. 図4の6つのグラフにおいて, 縦軸はいずれも新規性ポテンシャルの評価值 $(N P)$ であり, 横軸について は (a) が辞書類似度 $s_{l}\left(f_{1}, f_{2}\right)$, (b) が分布類似度 $s_{d}\left(f_{1}, f_{2}\right)$, (c) が補完類似度 $s_{c}\left(f_{1}, f_{2}\right)$ である.グラフ中の $R^{2}$ は決 定係数を，点線は回帰直線を表す.

相関分析の結果，得られた知見を下記にまとめる.

1. 全てのケースにおいて，計測した類似度と，新規性ポテンシャルの評価值との間に負の相関がみられる.

2. 実験 (A) に関しては，補完類似度 $s_{c}$ を用いたときに，決定係数 $R^{2} \simeq 0.59$ であり，有意水準 $5 \%$ の相関を示 している.これは 6 つケースの中で最も高い相関である.

3. 一方で, 実験 (B) に関しては, 補完類似度 $s_{c}$ の決定係数は $R^{2} \simeq 0.27$ である. これは分布類似度 $s_{d}$ の決定係 数 $R^{2} \simeq 0.34$ よりも低い.

4. 分布類似度 $s_{d}$ は, 実験 (A), 実験 (B) のいずれにおいても有意水準 $10 \%$ に達していない $(p$ 值はそれぞれ $17 \%$, 


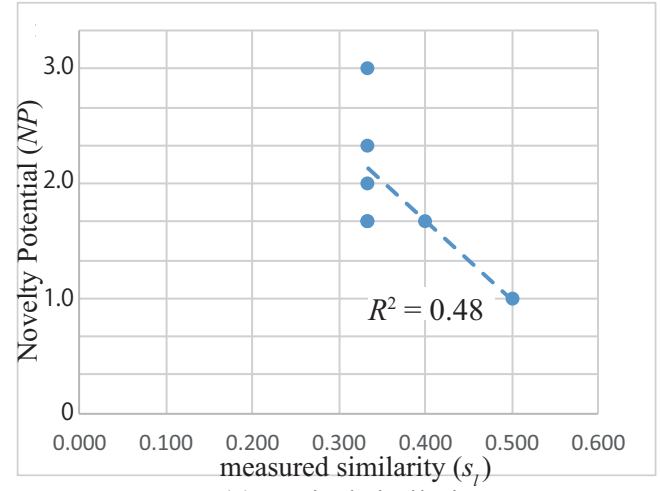

(a) Lexical similarity

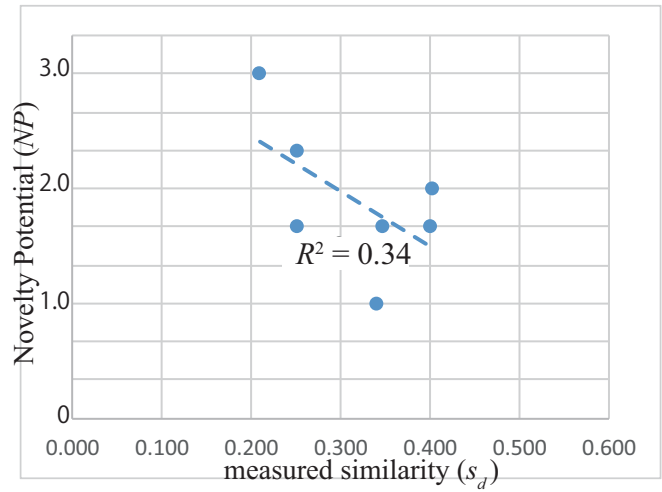

(b) Distributional similarity

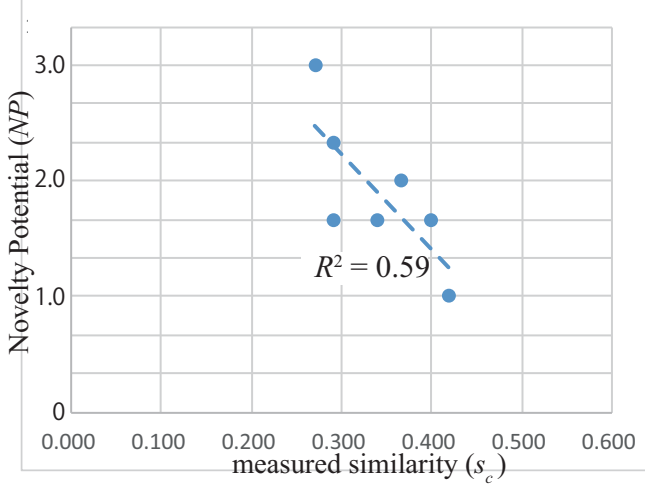

(c) Complemented similarity

(A) Pot-in-pot refrigerator

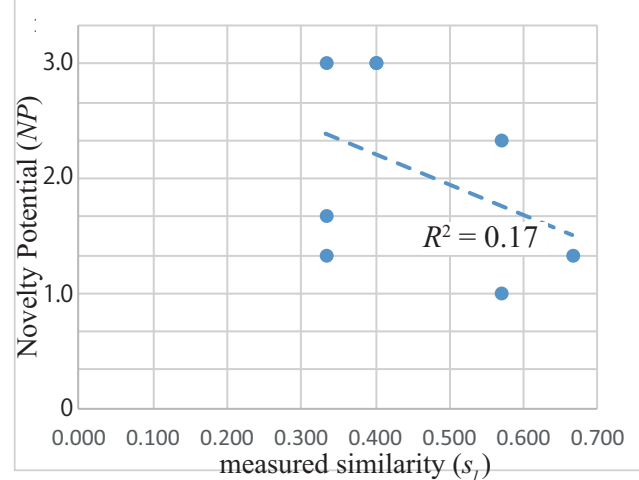

(a) Lexical similarity

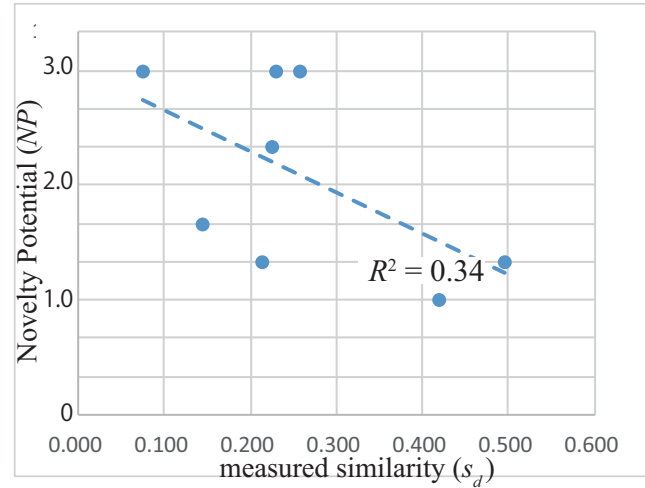

(b) Distributional similarity

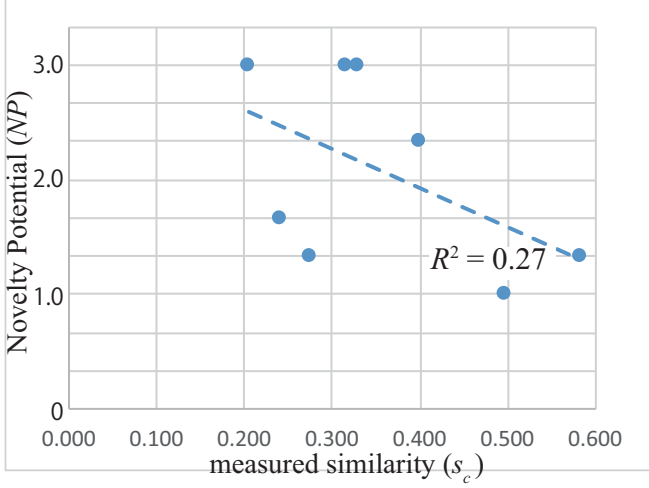

(c) Complemented similarity

(B) Adspecs

Fig. 4 Correlation analysis of novelty potential and function similarities. The results show that the measurement methods have the ability to assess the novelty potential of function concept combination.

$13 \%)$.

5. 辞書類似度 $s_{l}$ は実験 $(\mathrm{A})$ においては決定係数 $R^{2} \simeq 0.48$, 実験 $(\mathrm{B})$ においては決定係数 $R^{2} \simeq 0.17$ と, 相関に ばらつきが見られる。

\section{5. 考察}

\section{$5 \cdot 1$ 設計概念生成支援に向けた意味}

$4 \cdot 3$ 節の設計実験の結果により，機能概念間の距離と新規性ポテンシャルの間には正の相関があると言える.こ れは「組み合わせる 2 つ機能概念の距離が大きいほど新規性の高い概念が生成される」という本研究における 前提と一致する知見である.

より詳細に調べると, 補完類似度 $s_{c}$ および分布類似度 $s_{d}$ は高い相関係数を示しており，機能概念の組が持つ新 規性ポテンシャルを見積もる十分な能力があることを示唆している．新規性ポテンシャルは設計概念生成の有用 
Nomaguchi, Kawahara, Shoda and Fujita, Transactions of the JSME (in Japanese), Vol.86, No.890 (2020)

な手がかりになる考えである. データサイエンス技術に基づく機能概念の類似性の計測により，そのような新規 性ポテンシャルの見積もりを客観的な方法で行うことができることが示唆されている.

一方, 新たな設計概念の生成に向けては, デザイナーズチェアを一つの題材として取り上げて, カタログの文章 から既存の製品と機能概念を収集し，提案手法による新規性ポテンシャル計測を試みたところ，例えば,「年月を 経ても劣化しにくい」かつ「座る場所や人を選ばない」という機能概念の組は新規性ポテンシャルが高く, 実際, その 2 つ機能を持つチェアは前提としたカタログに含まれていない, すなわち, Voidであることを抽出するこ とができた. そのようにして新規性ポテンシャルの高いVoid とその根拠となっている機能概念の組を見つけるこ とができるようになれば, 本研究で提案した測定手法を ECF サイクルの中で用いることにより, 新規なアイデア を生み出す可能性が高い抽象概念の組み合わせを提示し, 設計者が設計概念生成を体系的に行えるようになるこ とが期待できる，なお，ここで述べた提案手法の新たな設計概念の生成への展開については，詳細を検討した上 で，別報として報告することを構想中である．

\section{$5 \cdot 2$ 測定の信頼性}

4.3 節で示した新規性ポテンシャル NP との相関分析によれば, 実験 (A) では 補完類似度 $s_{c}$ が最も高い相関を 示すものの, 実験 (B) では低い相関に留まることがわかった. これは 4.3 節で指摘した機能表現の違いに起因して いるものと考えられる. 実験 (A) の機能表現は修飾語を含んでおらず, また語数も少ないため, 機能概念の意味を 示すにあたり動詞がより主要な役割を果たしている. それゆえ辞書類似度による補完が効果を発揮したものと考 えられる. 対照的に, 実験 (B)の機能表現は修飾語を含みまた複合語が多用されており実験 (A) の機能表現より相 対的に動詞の役割が低い. そのため辞書類似度による補完の効果が相対的に薄いものと考えられる.

このことから，機能表現の柔軟性と測定の信頼性の間にはトレードオフの関係があると考えることができる．も し設計者が前者を重視するのであれば, 修飾語や複合語を用いた機能表現にも適した分布類似度の利用が効果的 である. 反対に, 設計者が後者を重視するのであれば, 動詞・目的語の形式で使用する語彙も限定した上で, 補 完類似度を用いるのが効果的である.

\section{6. 結 論}

革新的な設計概念生成のための理論や体系的方法論の構築は, 設計工学分野における挑戦的なテーマの一つで ある. それに向けて, 本研究では, まず, 設計において概念間の距離が果たす役割を踏まえて, 新規性ポテンシャ ルの考え方を導入した．これは，そもそも測定が困難な概念間の距離を，GDT における Void の考え方に基づい た概念生成を効果的に進めるために，すなわち，2つの機能概念の組み合わせにより新しい設計概念が生み出され る可能性の大きさを定量化するために導入したものである. その上で, 本報では, 新規性ポテンシャルの測定を, WordNet と word2 vec を応用した機能概念類似度測定法により行う方法を提案した. また, 設計概念生成支援に向 けた提案手法の可能性を，2つの題材による評価実験を通じて検証した. 概念設計段階における自由度の大きさを 踏まえれば，本研究で想定した機能表現の方法や，その類似度測定方法には検討の余地もある，今後は，様々な 特徵の対象を題材としたケーススタディーを通じて, 提案手法の汎用性および妥当性の検証を行う予定である.

本研究では, 類概念として機能概念のみを取り上げたが, 物理特性など各種の属性概念を使って設計要求や設 計解の表現を行うことも考えられる。一般に, 設計の上流段階では, どちらかといえば新規な設計概念を生成す ることが重視され，その有用性の具体的な評価は下流段階で行われる. そのため本研究では, 上流段階での設計 概念生成支援において不可欠な新規性評価に焦点を当てている．革新的な設計概念生成を実現するためには，2·1 節で述べたように，指標として，概念の新規性だけでなく有用性を考慮することも重要である.これらを踏まえ て, 提案手法を発展させていくことが今後の課題である.

\section{文献}

Altshuller, G., 40 Principles: TRIZ Keys to Technical Innovation, Extended edition (2005), Technical Innovation Center Worchester, MA. 
Chan, J., Fu, K., Schunn, C., Cagan, J., Wood, K. and Kotovsky, K., On the benefits and pitfalls of analogies for innovative design: Ideation performance based on analogical distance, commonness, and modality of examples, Journal of Mechanical Design, Transactions of the ASME, Vol. 133, No. 8 (2011), 081004.

Cheong, H., Li, W., Cheung, A., Nogueira, A. and Iorio, F., Automated extraction of function knowledge from text, Journal of Mechanical Design, Transactions of the ASME, Vol. 139, No. 11 (2017), 111407.

Daly, S., Seifert, C., Yilmaz, S. and Gonzalez, R., Comparing ideation techniques for beginning designers, Journal of Mechanical Design, Transactions of the ASME, Vol. 138, No. 10 (2016), 101108.

De Brentani, U., Innovative versus incremental new business services: Different keys for achieving success, Journal of Product Innovation Management, Vol. 18, No. 3 (2001), pp. 169-187.

Douali, M. and Silver, J., Self-optimised vision correction with adaptive spectacle lenses in developing countries, Ophthalmic and Physiological Optics, Vol. 24, No. 3 (2004), pp. 234-241.

Fu, K., Fuge, M. and Brown, D., Design creativity, Artificial Intelligence for Engineering Design, Analysis and Manufacturing: AIEDAM, Vol. 32, No. 4 (2018), pp. 363-364.

Georgiev, G. and Georgiev, D., Enhancing user creativity: Semantic measures for idea generation, Knowledge-Based Systems, Vol. 151 (2018), pp. 1-15.

Han, J., Shi, F., Chen, L. and Childs, P., A computational tool for creative idea generation based on analogical reasoning and ontology, Artificial Intelligence for Engineering Design, Analysis and Manufacturing: AIEDAM, Vol. 32, No. 4 (2018), pp. 462-477.

Hatchuel, A. and Weil, B., C-K design theory: An advanced formulation, Research in Engineering Design, Vol. 19, No. 4 (2009), pp. 181-192.

Mikolov, T., Chen, K., Corrado, G. and Dean, J., Efficient estimation of word representations in vector space (2013), arXiv:1301.3781v3.

Miller, G., WordNet: A lexical database for english, Communications of the ACM, Vol. 38, No. 11 (1995), pp. 39-41.

野間口大, 中切拓, 藤田喜久雄, 外在化・分類操作・Void 発見のサイクルと発明的問題解決理論の連係による発想支 援手法, 日本機械学会論文集, Vol. 83, No. 853 (2017), DOI:10.1299/transjsme.17-00122.

Rada, R., Mili, H., Bicknell, E. and Blettner, M., Development and application of a metric on semantic nets, IEEE Transactions on Systems, Man and Cybernetics, Vol. 19, No. 1 (1989), pp. 17-30.

Ranjan, B., Siddharth, L. and Chakrabarti, A., A systematic approach to assessing novelty, requirement satisfaction, and creativity, Artificial Intelligence for Engineering Design, Analysis and Manufacturing: AIEDAM, Vol. 32, No. 4 (2018), pp. 390-414.

Shah, J., Vargas-Hernandez, N. and Smith, S., Metrics for measuring ideation effectiveness, Design Studies, Vol. 24, No. 2 (2003), pp. 111-134.

Shimomura, Y., Yoshioka, M., Takeda, H., Umeda, Y. and Tomiyama, T., Representation of design object based on the functional evolution process model, Journal of Mechanical Design, Transactions of the ASME, Vol. 120, No. 2 (1998), pp. 221-229.

Smith, C. E., Design for the Other 90\% (2007), Editions Assouline, (邦訳 : 槌屋詩野 (監修), 北村陽子 (訳), 世界を変え るデザイン - ものづくりには夢がある -, (2009), 英治出版).

Suryadi, D. and Kim, H., A clustering and word similarity based approach for identifying product feature words, Proceedings of the International Conference on Engineering Design, ICED, Vol. 6, No. DS87-6 (2017), pp. 71-80.

Taura, T. and Nagai, Y., A systematized theory of creative concept generation in design: First-order and high-order concept generation, Research in Engineering Design, Vol. 24, No. 2 (2013), pp. 185-199.

冨山哲男, 設計の理論 (2002), 岩波書店.

Tomiyama, T., Breedveld, P. and Birkhofer, H., Teaching creative design by integrating general design theory and the Pahl \& Beitz methodology, Proceedings of the ASME Design Engineering Technical Conference, Vol. 6 (2010), pp. 707-715, DETC2010-28444.

山川宏, 最適設計ハンドブック - 基礎・戦略・応用 - (2003), 朝倉書店.

Yoshikawa, H. (Sata, T. and Warman, E. eds.), General Design Theory and a CAD System, Man-Machine Communication 
in CAD/CAM (1981), pp. 35-58, North-Holland, Amsterdam.

\section{References}

Altshuller, G., 40 Principles: TRIZ Keys to Technical Innovation, Extended edition (2005), Technical Innovation Center Worchester, MA.

Chan, J., Fu, K., Schunn, C., Cagan, J., Wood, K. and Kotovsky, K., On the benefits and pitfalls of analogies for innovative design: Ideation performance based on analogical distance, commonness, and modality of examples, Journal of Mechanical Design, Transactions of the ASME, Vol. 133, No. 8 (2011), 081004.

Cheong, H., Li, W., Cheung, A., Nogueira, A. and Iorio, F., Automated extraction of function knowledge from text, Journal of Mechanical Design, Transactions of the ASME, Vol. 139, No. 11 (2017), 111407.

Daly, S., Seifert, C., Yilmaz, S. and Gonzalez, R., Comparing ideation techniques for beginning designers, Journal of Mechanical Design, Transactions of the ASME, Vol. 138, No. 10 (2016), 101108.

De Brentani, U., Innovative versus incremental new business services: Different keys for achieving success, Journal of Product Innovation Management, Vol. 18, No. 3 (2001), pp. 169-187.

Douali, M. and Silver, J., Self-optimised vision correction with adaptive spectacle lenses in developing countries, Ophthalmic and Physiological Optics, Vol. 24, No. 3 (2004), pp. 234-241.

Fu, K., Fuge, M. and Brown, D., Design creativity, Artificial Intelligence for Engineering Design, Analysis and Manufacturing: AIEDAM, Vol. 32, No. 4 (2018), pp. 363-364.

Georgiev, G. and Georgiev, D., Enhancing user creativity: Semantic measures for idea generation, Knowledge-Based Systems, Vol. 151 (2018), pp. 1-15.

Han, J., Shi, F., Chen, L. and Childs, P., A computational tool for creative idea generation based on analogical reasoning and ontology, Artificial Intelligence for Engineering Design, Analysis and Manufacturing: AIEDAM, Vol. 32, No. 4 (2018), pp. 462-477.

Hatchuel, A. and Weil, B., C-K design theory: An advanced formulation, Research in Engineering Design, Vol. 19, No. 4 (2009), pp. 181-192.

Mikolov, T., Chen, K., Corrado, G. and Dean, J., Efficient estimation of word representations in vector space (2013), arXiv:1301.3781v3.

Miller, G., WordNet: A lexical database for english, Communications of the ACM, Vol. 38, No. 11 (1995), pp. 39-41.

Nomaguchi, Y., Nakagiri, T. and Fujita, K., Concept generation support with linkage of externalization-classificationfinding void cycle and theory of solving inventive problems, Transactions of the JSME (in Japanese), Vol. 83, No. 853 (2017), DOI:10.1299/transjsme.17-00122.

Rada, R., Mili, H., Bicknell, E. and Blettner, M., Development and application of a metric on semantic nets, IEEE Transactions on Systems, Man and Cybernetics, Vol. 19, No. 1 (1989), pp. 17-30.

Ranjan, B., Siddharth, L. and Chakrabarti, A., A systematic approach to assessing novelty, requirement satisfaction, and creativity, Artificial Intelligence for Engineering Design, Analysis and Manufacturing: AIEDAM, Vol. 32, No. 4 (2018), pp. 390-414.

Shah, J., Vargas-Hernandez, N. and Smith, S., Metrics for measuring ideation effectiveness, Design Studies, Vol. 24 , No. 2 (2003), pp. 111-134.

Shimomura, Y., Yoshioka, M., Takeda, H., Umeda, Y. and Tomiyama, T., Representation of design object based on the functional evolution process model, Journal of Mechanical Design, Transactions of the ASME, Vol. 120, No. 2 (1998), pp. 221-229.

Smith, C. E., Design For The Other 90\% (2007), Editions Assouline.

Suryadi, D. and Kim, H., A clustering and word similarity based approach for identifying product feature words, Proceedings of the International Conference on Engineering Design, ICED, Vol. 6, No. DS87-6 (2017), pp. 71-80.

Taura, T. and Nagai, Y., A systematized theory of creative concept generation in design: First-order and high-order concept generation, Research in Engineering Design, Vol. 24, No. 2 (2013), pp. 185-199.

Tomiyama, T., Theory of Design (2002), Iwanami (in Japanese). 
Tomiyama, T., Breedveld, P. and Birkhofer, H., Teaching creative design by integrating general design theory and the Pahl \& Beitz methodology, Proceedings of the ASME Design Engineering Technical Conference, Vol. 6 (2010), pp. $707-715$.

Yamakawa, H., Optimal Design Handbook (2003), Asakura Publishing (in Japanese).

Yoshikawa, H. (Sata, T. and Warman, E. eds.), General Design Theory and a CAD System, Man-Machine Communication in CAD/CAM (1981), pp. 35-58, North-Holland, Amsterdam. 